\title{
SUBSTITUSI SEBAGIAN RANSUM DENGAN MINYAK KELAPA TERHADAP PERFORMAN AYAM KAMPUNG SUPER PETELUR
}

\author{
Yobel Rori, Marie Najoan, Jein R. Leke*, Meity R. Imbar
}

Fakultas Peternakan Universitas Sam Ratulangi Manado 95115

\begin{abstract}
ABSTRAK
Penelitian ini bertujuan untuk mengetahui substitusi sebagian ransum dengan minyak kelapa terhadap performan ayam kampung super petelur. Penelitian ini telah dilaksanakan selama 8 minggu. Materi yang digunakan adalah 80 ekor ayam kampung super betina umur 5 bulan (awal bertelur). Penelitian menggunakan 5 perlakuan 4 ulangan dan rancangan yang digunakan adalah Rancangan Acak Lengakap (RAL) dilanjutkan dengan Uji Beda Nyata Jujur (BNJ). Perlakuan yang digunakan adalah : $\mathrm{R} 0=100 \%$ ransum basal $(\mathrm{RB})+0 \%$ minyak kelapa $(\mathrm{MK}), \mathrm{R} 1$ $=99,5 \% \mathrm{RB}+0,5 \% \mathrm{MK}, \mathrm{R} 2=99 \% \mathrm{RB}+$ $1 \% \mathrm{MK}, \mathrm{R} 3=98,5 \% \mathrm{RB}+1,5 \% \mathrm{MK}, \mathrm{R} 4=$ $98 \% \mathrm{RB}+2 \% \mathrm{MK}$. Hasil penelitian menunjukkan bahwa penggunaan minyak kelapa sampai $2 \%$ memberikan peningkatan terhadap produksi telur dan memberikan pengaruh yang sama terhadap konsumsi ransum dan konversi ransum. Dapat disimpulkan bahwa penggunaan minyak kelapa $2 \%$ dapat meningkatkan produksi telur dan memberikan konsumsi ransum dan konversi ransum yang sama.
\end{abstract}

Kata Kunci : Ayam Kampung Super Petelur, Minyak Kelapa.

*Korespondensi (corresponding author): Email: rinileke@unsrat.ac.id

\begin{abstract}
SUBSTITUTION OF SOME RATION WITH COCONUT OIL ON THE PERFORMANCE OF LAYING SUPER NATIVE CHICKEN. The pupose of the research is to knowing the substitution of some ratio with coconut oil on the performance of laying super native chicken. this research already implemented during 8 weeks. The material used in this study was a 80 laying hens super native chicken aged 5 month. The research design used was the completely randomized design (CDR) with 5 treatment and 4 replications. Tukey test was used for further test. Treatments were formulated as follow : R0 $=100 \%$ control diet $+0 \%$ Coconut Oil $(\mathrm{CO}) ; \mathrm{R} 1=99.5 \%$ control diet $+0.5 \% \mathrm{CO}$; $\mathrm{R} 2=99 \%$ control diet $+1 \% \mathrm{CO} ; \mathrm{R} 3=$ $98.5 \%$ control diet $+1.5 \% \mathrm{CO} ; \mathrm{R} 4=98 \%$ control diet $+2 \% \mathrm{CO}$. The result showed that applying the coconut oil until $2 \%$ giving increase for egg production and giving the same effect for feed consumtion and feed conversion.
\end{abstract}

Keywords : laying super chicken native, coconut oil.

\section{PENDAHULUAN}

Ayam merupakan ternak yang sudah banyak dipelihara oleh masyarakat. Peternakan ayam menambah penghasilan keluarga atau rumah tangga dan dapat mendukung ekonomi pedesaan serta memenuhi kebutuhan protein masyarakat. 
Populasi ayam kampung pada tahun 2018 mencapai 310.959.951 ekor (Ditjen Peternakan dan Keswan, 2018). Peningkatan kebutuhan protein hewani untuk masyarakat semakin berkembang dengan memaksimalkan produktivitas ayam kampung, salah satunya berasal dari ternak ayam kampung super. Ayam kampung super berasal dari persilangan genetik antara ayam buras pejantan lokal dengan ayam ras petelur betina. Pengembangan ayam kampung super saat ini sangat cepat dan merupakan ternak yang telah menyebar di seluruh pelosok nusantara. Ayam kampung mempunyai 3 fase pemeliharaan yaitu fase starter (DOC 8 minggu), fase grower ( $9-20$ minggu) dan fase layer (umur lebih dari 20 minggu). Resnawati dan Ida (2014) menyatakan selama fase pertumbuhan kebutuhan protein ayam kampung yaitu $14 \%$ dan energi metabolisnya $2600 \mathrm{Kcal} / \mathrm{kg}$, sedangkan untuk fase bertelur proteinnya $17 \%$ dan energi metabolis $3200 \mathrm{Kcal} / \mathrm{kg}$.

Telur ayam adalah produk yang diperlukan untuk memenuhi kecukupan gizi masyarakat. Produksi telur ayam kampung yaitu 60-90 butir telur per ekor per tahun dan berat telur 40 gram. Ayam kampung super mencapai dewasa kelamin pada umur 150 hari serta mempunyai tiga periode bertelur dalam setahun dan hen day production mencapai 32,5\%. Untuk mencapai produksi telur ayam kampung super maka dibutuhkan ransum dengan imbangan protein $17 \%$ dan energi metabolis $2750 \mathrm{Kcal} / \mathrm{kg}$ (Suprijatna, 2007). Protein dan asam lemak sangat mempengaruhi kuantitas dan kualitas telur. Energi juga menjadi salah satu faktor penunjang optimalisasi pertumbuhan ternak ayam dan salah satu bahan pakan sumber energi serta mempunyai asam-asam lemak adalah minyak kelapa.

Sulawesi Utara merupakan Provinsi yang menghasilkan buah kelapa. Produksi buah kelapa di Sulawesi Utara pada tahun 2017 sebanyak 265.637 ton buah kelapa (Direktorat Jendral Perkebunan, 2017). Buah kelapa dalam dapat dijadikan minyak kelapa. Pembuatan minyak kelapa dapat dilakukan dengan cara tradisional. Proses pembuatan 1 liter minyak kelapa berasal dari 10 biji buah kelapa dalam. Minyak kelapa yang dibuat sendiri dengan cara fisik memiliki keunggulan sebagai sumber energi dan mempercepat metabolisme energi, serta tidak mengandung pengawet.

Berdasarkan uraian diatas sudah dilaksanakan penelitian untuk mengetahui pengaruh substitusi minyak kelapa dalam ransum ayam kampung super petelur terhadap performan ayam kampung super petelur. 


\section{MATERI DAN METODE PENELITIAN}

\section{Proses Pembuatan Minyak Kelapa}

Buah kelapa didapatkan dari daerah Minahasa dan minyak kelapa yang dibuat sendiri. Proses pembuatan minyak kelapa yaitu belah kelapa 10 buah, cukur daging buah kelapa dari batok sampai menjadi ampas, tuangkan air panas sebanyak 3 liter kedalam wadah, peras ampas kelapa sampai mengeluarkan santan, dan diamkan selama 24 jam, setelah itu ambil bagian atas lalu dimasak sehingga menghasilkan 1 liter minyak kelapa.

\section{Materi Penelitian}

Penelitian menggunakan 80 ekor ayam kampung super petelur berumur 20 minggu, kandang baterai diberi tempat makan dari bambu dan tempat minum plastik/cup. Perlengkapan lain yang digunakan adalah timbangan (untuk menimbang ransum, minyak kelapa dan telur), wadah penampung minyak kelapa, dan alat tulis untuk mencatat hasil penelitian. Pembelian bahan pakan diambil dari toko pakan "setia jaya" Manado dan susunannya yaitu jagung (50\%), dedak halus (17), tepung ikan (13\%), dan bungkil kelapa (19,5\%). Minyak kelapa yang digunakan selama penelitian sebanyak 16 liter. Rancangan yang digunakan yaitu RAL dengan 5 perlakuan dan 4 ulangan.

Tabel 1. Komposisi Ransum Kontrol

\begin{tabular}{lc}
\hline \multicolumn{1}{c}{ Bahan Makanan } & Penggunaan (\%) \\
\hline Jagung & 50 \\
Tepung Ikan & 13 \\
Bungkil Kelapa & 19,5 \\
Dedak Halus & 17 \\
Top Mix & 0,5 \\
\hline \multicolumn{1}{c}{ Jumlah } & 100 \\
\hline
\end{tabular}


Tabel 2. Komposisi Nutrien dan Energi Metabolis Ransum Percobaan

\begin{tabular}{llllll}
\hline Perlakuan & $\mathrm{R} 0$ & $\mathrm{R} 1$ & $\mathrm{R} 2$ & $\mathrm{R} 3$ & $\mathrm{R} 4$ \\
\hline Ransum & 100 & 99,5 & 99 & 98,5 & 98 \\
Minyak Kelapa & 0 & 0,5 & 1 & 1,5 & 2 \\
\hline Total & 100 & 100 & 100 & 100 & 100 \\
\hline Zat Makanan/Energi & $\mathrm{R} 0$ & $\mathrm{R} 1$ & $\mathrm{R} 2$ & $\mathrm{R} 3$ & $\mathrm{R} 4$ \\
\hline Protein (\%) & 17,97 & 17,88 & 17,79 & 17,70 & 17,61 \\
Lemak (\%) & 6,10 & 6,10 & 6,10 & 6,10 & 6,10 \\
Serat Kasar (\%) & 5,60 & 5,57 & 5,54 & 5,51 & $5 \backslash, 48$ \\
Ca $(\%)$ & 3,22 & 3,21 & 3,20 & 3,19 & 3,18 \\
P (\%) & 1,46 & 1,45 & 1,44 & 1,43 & 1,42 \\
EM (Kkal/Kg) & 2715 & 2733 & 2751 & 2769 & 2786 \\
\hline
\end{tabular}

\section{Variabel yang diukur :}

1. Konsumsi ransum dapat dihitung :

Ransum yang diberikan (g/ekor/hari)

- ransum sisa (g/ekor/hari)

2. Produksi Telur atau hen day production (\%) dapat dihitung : Jumlah telur yang dihasilkan (ekor/hari) Jumlah ayam yang hidup pada hari itu x $100 \%$

3. Konversi ransum dapat dihitung : Konsumsi Ransum (g/ekor) Berat telur (g/ekor)

\section{Analisis Data}

Analisis data menggunakan microsoft excel 2010 dan secara statistik menggunakan rancangan acak lengkap (RAL). Apabila terdapat perbedaan diantara perlakuan dilakukan uji lanjut
Beda Nyata Jujur (BNJ) (Steel and Torrie, 1994).

\section{HASIL DAN PEMBAHASAN}

\section{Pengaruh perlakuan terhadap konsumsi ransum}

Rataan konsumsi ransum setiap level minyak kelapa yaitu R0 $(87,63$ gr/ekor/hari), R1 (86,97 g/ekor/hari), R2 (86,91 g/ekor/hari), R4 (86,77 g/ekor/hari), R3 (86,73 g/ekor/hari). Konsumsi ransum ayam kampung yaitu 86-100 gr/ekor/hari (Trisiwi, 2017).

Analisis keragaman dari substitusi minyak kelapa pada level $0 \%-2 \%$ memberikan konsumsi ransum yang sama. Konsumsi ransum yang sama karena imbangan energi dan protein yang 
Tabel 3. Pengaruh Level Substitusi Minyak Kelapa Terhadap Performan Ayam.

\begin{tabular}{llllll}
\hline Variabel & \multicolumn{5}{c}{ Perlakuan } \\
\cline { 2 - 6 } & $0 \%$ & $0,5 \%$ & $1 \%$ & $1,5 \%$ & $2 \%$ \\
\hline $\begin{array}{l}\text { Konsumsi Ransum } \\
\text { gram/ekor/hari) }\end{array}$ & $87,63 \pm 0,36$ & $86,97 \pm 0,15$ & $86,91 \pm 0,50$ & $86,73 \pm 0,33$ & $86,77 \pm 0,62$ \\
\hline $\begin{array}{l}\text { Produksi Telur } \\
\text { HDP }(\%)\end{array}$ & $38,50^{\mathrm{a}} \pm 0,67$ & $38,95^{\mathrm{ab}} \pm 0,76$ & $38,62^{\mathrm{ab}} \pm 1,18$ & $40,07^{\mathrm{ab}} \pm 1,05$ & $41,18^{\mathrm{b}} \pm 2,01$ \\
\hline Konversi Ransum & $5,17 \pm 0,04$ & $5,14 \pm 0,10$ & $5,10 \pm 0,13$ & $5,09 \pm 0,07$ & $4,92 \pm 0,16$ \\
\hline
\end{tabular}

Keterangan: Superskrip yang berbeda pada kolom yang sama artinya berbeda nyata $(\mathrm{P}<0,05)$

digunakan hampir sama. Wahyu (1985) menyatakan imbangan energi metabolis dan protein dalam ransum menentukan konsumsi ransum sehingga mempengaruhi produksi telur. Sanyoto dan Riyanto (2004) Menyatakan bahwa tingkatan kandungan energi dalam ransum menjadi faktor penentu konsumsi ransum. Tamawiwy et al. (2016) menambahkan bahwa minyak kelapa yang diberikan pada ternak tidak berpengaruh dari palatabilitas. Nuraini dan Latif (2012) menyatakan kualitas, kuantitas ransum, aktivitas ternak, umur, kesehatan ternak sangat mempengaruhi konsumsi ransum ayam kampung super.

\section{Pengaruh Perlakuan Terhadap Produksi Telur (Hen Day Production)}

Rataan produksi telur ayam kampung super yang menggunakan minyak kelapa dalam penelitian ini yaitu $38,50 \%-41,18 \%$ (Tabel 3). Nataamijaya (2008) mengungkapkan produksi telur ayam kampung berkisar antara 30\% - 40\%.
Penggunaan minyak kelapa level 0\% - 2\% dapat meningkatkan produksi telur. Hasil uji lanjut BNJ menunjukkan R3 dan R4 lebih tinggi dibandingkan dengan perlakuan R0 tetapi antara $\mathrm{R} 0, \mathrm{R} 1, \mathrm{R} 2$, dan R3 menghasilkan produksi telur yang sama. Artinya substitusi minyak kelapa sampai 2\% (R4) dalam ransum memberikan produksi telur yang tertinggi dibanding dengan lainnya.

Terjadi peningkatan produksi telur pada perlakuan karena minyak kelapa sampai $2 \%$ mengandung asam lemak. Menurut Carandang (2008) asam lemak seperti linoleat, laurat, dan kaprat yang terkandung dalam minyak kelapa berguna untuk meningkatkan metabolisme tubuh dan menambah energi. Minyak kelapa yang diberikan dapat mengoptimalkan produk energi yang dihasilkan, sehingga asam lemak dari minyak kelapa tidak terakumulasi sebagai deposit lemak dan tidak menyebabkan penimbunan lemak serta memberikan dampak terhadap produksi telur. Menurut Prawitasari et al. 
(2012) Pemberian dan kualitas ransum menjadi faktor penentu dalam produksi telur.

\section{Pengaruh Perlakuan Terhadap Konversi Ransum}

Rataan konversi ransum ayam kampung super yang menggunakan minyak kelapa dari yang tertinggi yaitu R0 $(5,17)$, R1 (5,14), R2 (5,10), R3 (5,09), R4 (4.92). Hidayat et al., (2011) menyatakan bahwa konversi ransum ayam kampung fase layer awal yaitu 4,85-7,29.

Analisis sidik ragam menghasilkan konversi ransum yang sama pada level $0 \%$ - 2\%. Minyak kelapa mempunyai asam lemak jenuh dapat merangsang proses metabolisme pembentukan telur, selain dipengaruhi oleh asupan nutrien lain sehingga bobot telur yang dihasilkan

semakin baik dan konversinya semakin menurun. Hurwits et al. (1998) mengemukakan bahwa konversi ransum yang mengalami penurunan berarti bahwa penggunaan ransum yang diberikan semakin efisien.

Pada penelitian ini semakin tinggi presentasi minyak kelapa didalam ransum maka angka konversi ransum semakin menurun. Menurut Lacy dan Vest (2000) yang disitasi oleh Fahrudin et al. (2017) menyatakan genetik, bentuk fisik ransum, dan komposisi nutrient sangat mempengaruhi konversi ransum.

\section{KESIMPULAN}

Kesimpulan dari penelitian ini yaitu pemberian minyak kelapa sampai level $2 \%$ dapat meningkatkan produksi telur serta memberikan konsumsi ransum dan konversi ransum yang sama.

\section{UCAPAN TERIMA KASIH}

Penelitian didanai oleh Bidang Kerjasama Universitas Sam Ratulangi yaitu kegiatan kerjasama Fakultas Peternakan Universitas Sam Ratulangi dengan Fakultas Peternakan Universitas Padjadjaran. Terima kasih kepada Prof. Dr. Ir. Tuty Widjastuti, MS sebagai mitra kerjasama penelitian ini.

\section{DAFTAR PUSTAKA}

Carandang, E. V. 2008. Health benefits of Virgin Coconut. Indian Coconut Journal-Cochin Vol 31(2) : 8-12.

Direktorat Jendral Perkebunan. 2017. Statistik Perkebunan Indonesia Komoditas Kelapa 2015-2017. Diterbitkan Oleh Sekretariat Direktorat Jendral Perkebunan.

Direktorat Jendral Peternakan dan Kesehatan Hewan. 2018. Statistik Peternakan dan Kesehatan Hewan. Penerbit Direktorat Jendral Peternakan dan Kesehatan Hewan. 
Fahrudin A., W. Tanwiriah dan I. Heni. 2017. Konsumsi ransum, pertambahan bobot badan dan konversi ransum ayam lokal di Jimmy's Farm Cipanas Kabupaten Cianjur. Students e-Journals. Vol 6(1) : 1-8.

Hidayat, C., S. Iskandar, dan T. Sartika. 2011. Respon kinerja perteluran ayam kampung unggul balitnak (KUB) terhadap perlakuan protein ransum pada masa pertumbuhan. Jurnal Ilmu Ternak dan Veteriner. Vol 16(2) : 83-89.

Hurwits, S., D. Sklan, H. Talpas, dan I. Plavrik. 1998. The Effect of dietary protein level on the lysine and arginine requrements of growing chicken. Journal Poultry Science. 77 : 696-698.

Nataamijaya, A. G. 2008. Karakteristik dan produktivitas ayam kedu hitam. Buletin Plasma Nutfah. e-journal litbang pertanian. Vol 14(2): 85-89.

Nuraini, S. dan S. A. Latif. 2012. Fermented product by monacus purpureus in poultry diet effects on laying performance and egg quality. Pakistan Journal Of Nutrion. 11 : 507-510.

Prawitasari, R. H., V. D. Y. B. Ismadi, dan I. Estiningdriati. 2012. Kecernaan protein kasar dan serat kasar serta laju digesta pada ayam arab yang diberi ransum dengan berbagai level Azolla

Korespondensi :

yobelrori@gmail.com
Mcirophylla. Animal Agriculture journal. Vol. 1(1) : 471-483.

Resnawati H. dan A.K.B. Ida 2014. Kebutuhan Pakan Ayam Kampung Pada Periode Pertumbuhan. Balai Penelitian Ternak. Bogor.

Sanyoto, J. I., dan J. Riyanto. 2004. Penggunaan minyak kelapa dan lemak sapi sebagai sumber energi ransum broiler. Journal of the Indonesian Tropical Animal Agriculture 29 (3), 148-155

Steel, R. G. D. and J. H. Torrie. 1994. Principles and Procedures of Statistics. Mc Graw-Hill Book Co, Inc. Pub. Ltd, London.

Suprijatna, E. 2007. Ayam Buras Krosing Petelur. Penebar Swadaya. Jakarta.

Tamawiwy, A., M. Najoan, J. Mandey, F. N. Sompie. 2016. Pengaruh Penggunaan virgin coconut oil (VCO) dalam ransum terhadap performans ternak babi fase starter. Jurnal Zootek. Vol. 36(1): 86-94.

Trisiwi, H. F. 2017. Respon kinerja peteluran ayam kampung super betina terhadap level protein pakan pada masa pertumbuhan. Jurnal Sains Peternakan Indonesia. Vol. 12(1) : 83-93.

Wahyu, J. 1985. Ilmu Nutrisi Unggas. Gadjah Mada University Press, Yogjakarta. 